$622.7(344) 65$

\title{
閃悪鉊鉱(微細鉱粒)の浮遊性におよぼす電解質の影響”
}

\author{
正会員向并滋** \\ 准会員森, 川薰淳炈
}

\section{Effect of Electrolytes on the Floatability of Fine Particles of Zincblende}

Shigeru MUKAI and Masakiyo MORIKAWA

\begin{abstract}
To make the floatability of fine mineral particles clear, an attempt has been made to determine the relation between the flocculation of fine particles and their floatability.

Electrolytes $\left(\mathrm{NaCl}, \mathrm{AgNO}_{3}, \mathrm{CuSO}_{4}, \mathrm{ZnSO}_{4}\right.$ and $\mathrm{Na}$-alginate) have been added as flocculant and then the flocculation of fine particles of zincblende has been observed through the photometer and the floatability of $-1 \mu$ and $150-300$ mesh particles of zincblende has been determined by the flotation testing.

The results of the experiments are as follows.

(1) The floatability of $150-300$ mesh particles is nearly the maximum but the floatability of $-1 \mu$ particles is extremely low in the wide range of $\mathrm{pH}$ in the pulp.

(2) The floatability of $-1 \mu$ particles is extremely low when the mineral particles are dispersed in the pulp but their floatability rises nearly the highest when the flocculation is stimulated by adding the electrolytes in the pulp.

(3) The floatability of $150-300$ mesh particles is extremely high in the wide range of concentration of the electrolytes. Therefore the effect of the electrolytes used in this experiment on the coarse particles is not so remarkable as no the fine particles.
\end{abstract}

\section{1. 緒一言}

鈗物粒子の浮遊性飞関する電解質の影響については多 くの研究がなされている。W. Petersen ${ }^{1)}$ 氏は鈗粒の 㠜集または分散と浮遊性との関係を指摘し，A.F. Taggart, T. C. Taylor, A. F. Knoll2) 氏は鉣粒のブラウ ン運動和よび分散が浮遊性に望ましくな結果を与兄る と述へ，O. Sommer ${ }^{3)}$ 氏は高陵土の浮選㠜集が著し (影響をるつことを確め，E. Edser ${ }^{4}$ 氏特よび H. L. Sulman ${ }^{5)}$ 氏は凝集が浮選の必要条件であると述へてい る。A. M. Gaudin' ${ }^{6}$ 氏はこれ疑義を示し，N.W. Taylor, H. B. Bull 7 氏 を低下させることを報告し，大山正）教授は鉣粒の㠜集 または分散は鉣粒の浮遊影響を与兄る場合とあた学ぬ 場合とがあることを示している。A. F. Taggart, G. R. M. del Giudice, O. A. Zieh19) 氏は鉱粒のブラウ ン運動および分散と非浮遊性とは密接な関係にあり, こ れらは分散粒子の表面の状態に起因すると述へ，A. W.

\footnotetext{
* 昭和31年11月12日受理

昭和30年 4 月, 日本鉱業会春季学術講演会に.て講演

** 工博, 京都大学教授, 鉱山学教室

*** 九州大学助手, 生產科学研究所
}

Fahrenwald, J. Newton ${ }^{10)}$ 氏は石英粒子の浮楃性に対 する電解質の影響について電気化学的推論を行い, T. C. Fitt, A. W. Thomas, A. F. Taggart ${ }^{11)}$ 氏は閃亜 鉛鉱の微細粒子は分散状態で浮遊しないと述心ている。 一方䊗谷敬12) 氏は DTA 溶液中の珪石について寨験の 結果, 釷粒の沈降速度々浮遊性々の閒汇一定の関係は認 められないと報告している。

以上の上ら従来の研究の結果は必ずしも一致を見る に至らない。しかし鉣粒の凝集杂たは分散は鉣粒の表面 の状態に基づくもので, これらと鈗粒の浮遊性との関係 を求めることは鉣物の浮遊性の本質にする的，浮選法の 実際操業儿も関係し，かつ浮遊性の著しく低、微細鉣粒 の回収にるつながり重要な問題の一つと思われる。

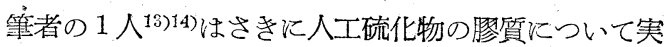
験の結果, 膠質分散状態に和ける浮遊率は添とんぞ 0で あるが電解質を添加し凝結を促進した場合浮遊率は 100 \%に近く上昇寸ることを明らかてした。本研究は人工硫 化物膠質について認められた現象が天然硫化鉣物につい てる認められるか否かを確め, 電解質の鉣物浮遊性飞特 よ注す影響を膠質化学的観点から明らか沉すこ之を目 的としてて遂行したものである。 


\section{2. 実 馱 法}

(1) 試料

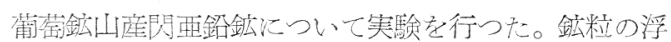

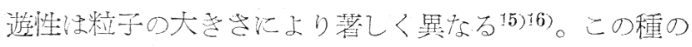
実験至混合椟度の試料飞ついて行うことほ現象の明確な

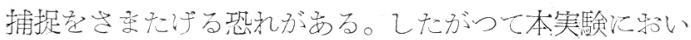
ては比較的粗大な粒子（150～300 mesh）和上びきわる て微細な粒子 $(-1 \mu)$ について赛験を行つた。

約 1 $3 \mathrm{~mm}$ ○粒子飞ついて純粋粒子老手選し, 次飞 瑪瑙孚鍊で摩砕乙， $-1 \mu$ 䊀子小水中沈降法汇より，150 〜300mesh 鉱䊀はタイラー標淮フルイにより分粒し実 墟供した。150〜300mesh 試料中以混大する微細粒子 はデカンテーション法により除外した。

試料の粒子の大きさほー1 鏡，150〜300mesh 粒子そついては光学顕微鏡により測 定した結果，一 $-1 \mu$ 粒子は $0.82 \sim 0.01 \mu$ 平均の大きさ

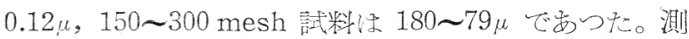

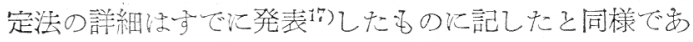
る。写真 1,2 は試料粒子の影微鏡写真を示す。

\section{（2）浮選試験}

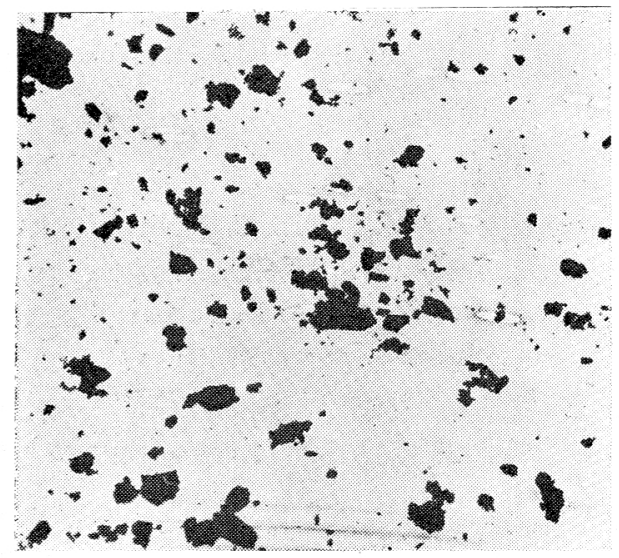

写真1 閃亚鉛鉱 $,-1 \mu,(10,000$ 倍工 2 亿縮写 $)$

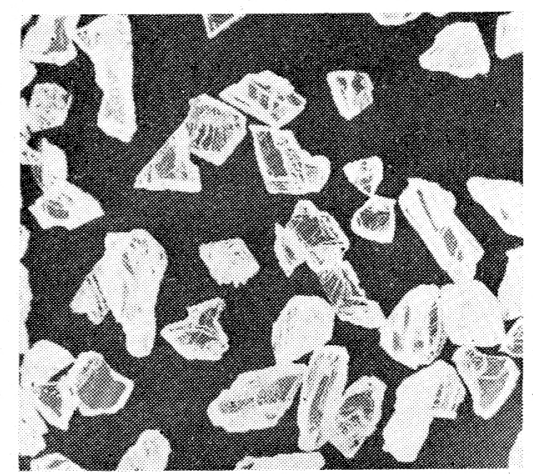

写真2 閃亚鉛鉱，150～300mesh(100倍／２に維写）
試験機：M.S. 型, 容量 $240 \mathrm{cc}$, 回転数 $2,900 \mathrm{rpm}$

浮選郕：カリ・エチール・ザンセート……....

$0.1 \%$ 溶液 $5 \mathrm{cc}$

$$
\begin{aligned}
& \text { エー・フコート25\# } \\
& \text { ヤーマーFパイン油 }
\end{aligned}
$$

コンディショニング5分，泡沫採取 10分

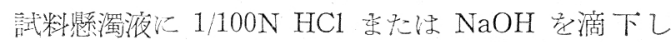

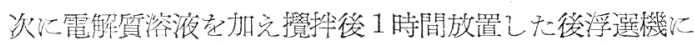
入れ浮選試験を行つた。鉣液の $\mathrm{pH}$ は硝子電椣により測 是した。実鈳に使用した水以すへて 2 回蒸溜をくり返乙 た蒸溜水である。浮遊率は一ー1

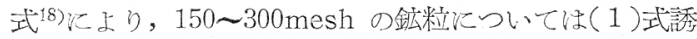
尊の前提である泡沫採取化伴引鉣液汲み出しの影響が少 ないことを確めたので(2)式以より算出した。

$$
\begin{gathered}
\text { 浮遊率 }=\left(1-\frac{S}{V \cdot f \cdot e^{-b}}\right) \times 100 \% \\
b=W / V
\end{gathered}
$$

$S$ : 浮選試験終了後の浮選機内残留鉣物の重量 $(\mathrm{g})$. $f:$ 試料鉱液の濃度 $(\mathrm{g} / \mathrm{cc})$

$V:$ 浮選機内 0 液量 $(\mathrm{cc})$

$W:$ 泡沭採取に伴い加兑た水の量 $(\mathrm{cc})$

$$
\text { 浮遊率 }=\frac{S}{F} \times 100 \%
$$

$F^{\prime}$ : 試料の重量 $(\mathrm{g})$

\section{(3) 鉱粒の凝集}

鈯粒の凝集秀たは分散の状態は光電管により測定し た。光電管による測定は第1㘡に示す装置を使用した。 $\mathrm{B}$ : 不箱; $\mathrm{P}$ : 光電管, 東京芝浦電気製, PL-50-V, 陰 㯪也シューム； C：キュペット； $\mathrm{S}_{1}, \mathrm{~S}_{2}$ ：スリット； $\mathrm{F} ：$ 熱線吸収用液相フィルター； J : 絞り； $l:$ ィズ; $\mathrm{L}$ : 光源ランプ，マツダ100ワット電球；S.T.：自働電圧調 整器; $V_{1}, V_{2}$ : ボルトメーター； $R$ : 真空管整流装置; $\mathrm{G}$ : 検流胡，横河製 D-3 型，感度 $2.4 \times 10^{-10} \mathrm{~A}, 2.7 \times$

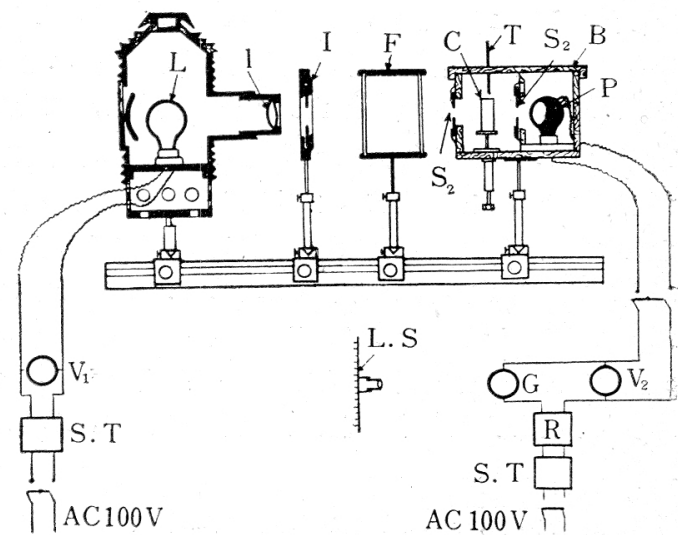

第1図 光電管による測定装置 


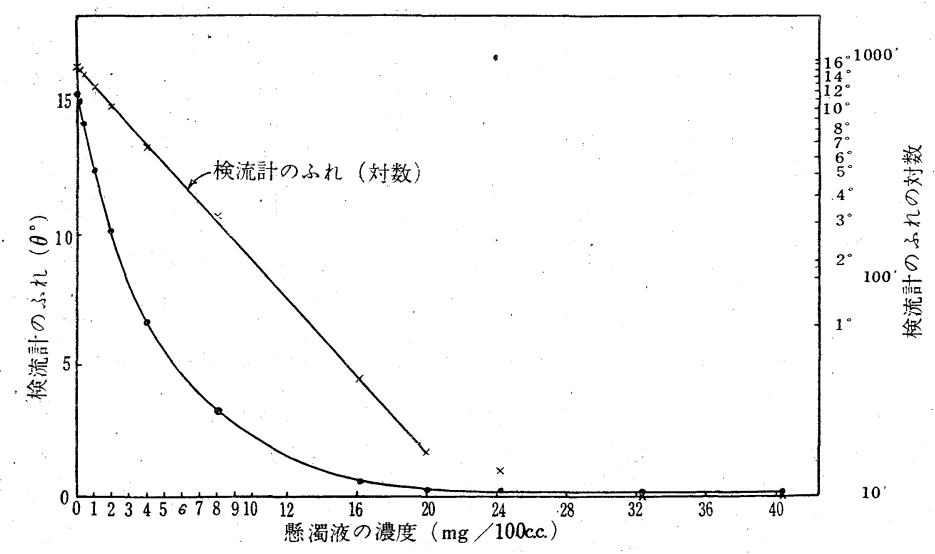

第 2 図㲘濁液の濃度と検流計のふれ

$10^{-6} \mathrm{~V} ; \mathrm{LS}:$ : ンプスケール ; 光電管の陽極電圧は 150 $\mathrm{V}$, 装置は恒温室 $\left.{ }^{19}\right)$ 内に置き $20^{\circ} \mathrm{C}$ に和いて測定を行つ た。

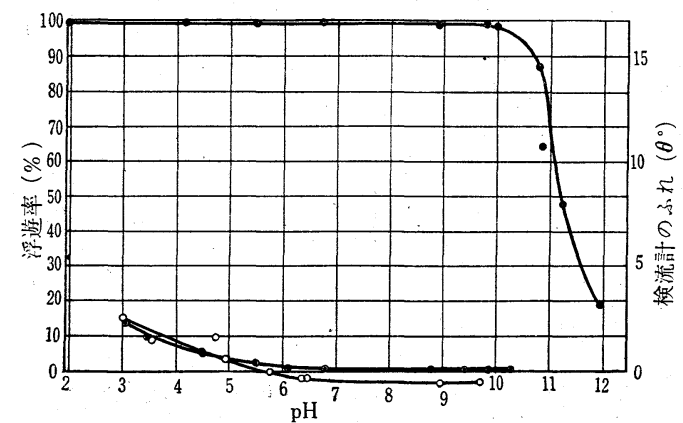

$$
\text { ○一○ }-1 \mu \text { の浮遊率 ๑一—— }-1 \mu \text { の检流計のふれ }
$$$$
\text { -— 150 300mesh の浮游率 }
$$

第 3 図閃亜鉛鉱の浮遊率ならびに凝集に怙よぼす $\mathrm{pH}$ の影響

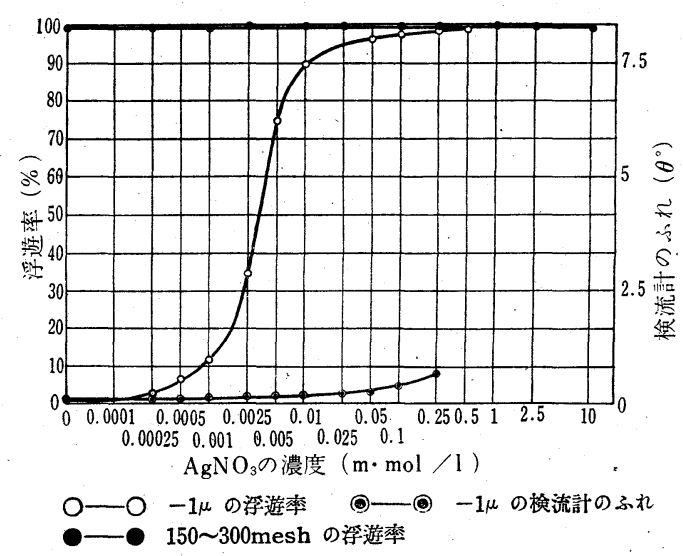

第 5 図閃亜鉛鉱の浮遊率ならびに凝集におよぼす $\mathrm{AgNO}_{3}$ の影響

*検流計のふれは検流計の鏡の回転角の 2 倍に相当する角度の数字を るつて示しれ。
本装置による懸濁液の濃度と検流計の られ*との関係は第2図に示すようであ る。懸濁液の濃度が $20 \mathrm{mg} / 100 \mathrm{cc}$ より小 なる時は濃度の減少にしたがい検流計の ふれは顕著に变化する。検流計のふれの 対数は懸濁液の濃度 $20 \mathrm{mg} / 100 \mathrm{cc}$ 以下に 末いて㲘濁液の濃度の変化にしたがい直 線的儿变化する。本実験以試粼懸濁液の 濃度 $20 \mathrm{mg} / 100 \mathrm{cc}$ に新いて行つた。

$-1 \mu$ 鉣粒の懸濁液をとり $1 / 100 \mathrm{NHCl}$ 禾たは $\mathrm{NaOH}$ 溶液を加え $\mathrm{pH}$ を調節し， これに電解質溶液を加兄復抖後直ちにキ ュペットルとり静置し 1 時間後光電管に より観測した。

\section{3. 実験結果および考察}

実験結果は第 3〜8 款よび 11,12図に示す。第3図は 閃覀鉛鉣の浮遊率と鉣液の $\mathrm{pH}$ との関係を示したるので

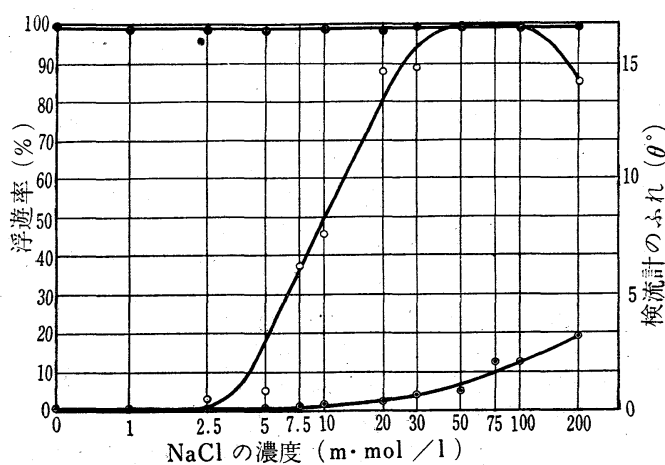

$$
\begin{aligned}
& \text { ○一○ }-1 \mu \text { の浮遊率 (๑一—— }-1 \mu \text { の検流計のふれ } \\
& \text {-— 150 300mesh の浮遊率 }
\end{aligned}
$$

第4図 閃亜鉛鉱の浮遊率ならびに㠜集に扣よぼす $\mathrm{NaCl}$ の影響

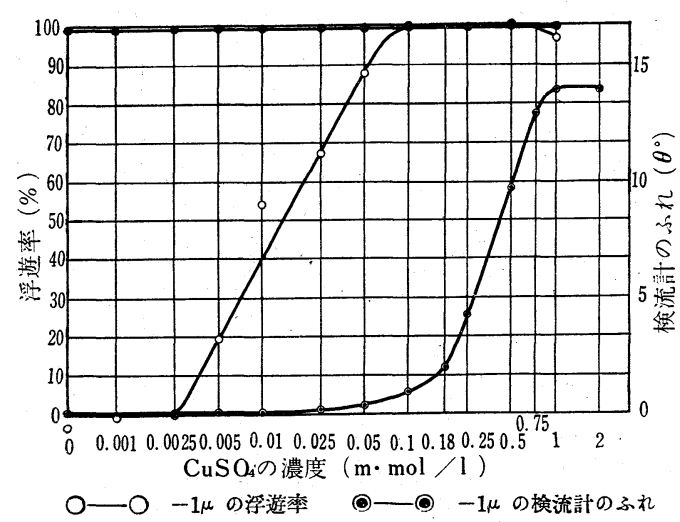

-—150 300mesh の浮遊柰

第 6 図: 閃亜鉛鉱の浮遊率ならびに凝集におよ洔す $\mathrm{CuSO}_{4}$ の影響 


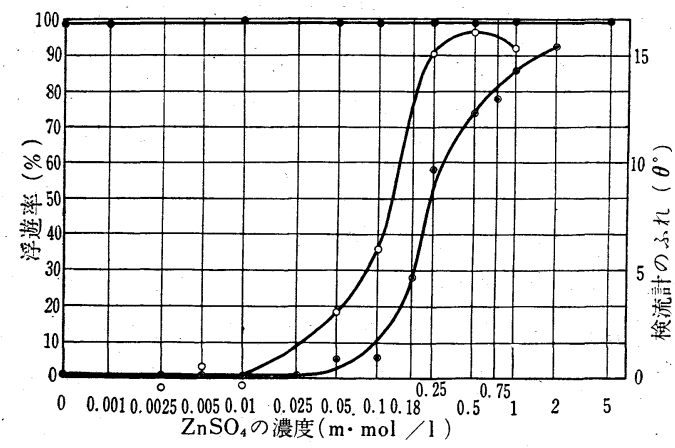

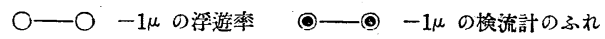

-— 150 300 mesh の浮遊率

第 7 図閃亜鉛鈗の浮遊率ならびに凝集におよぼす $\mathrm{ZnSO}_{4}$ の影響

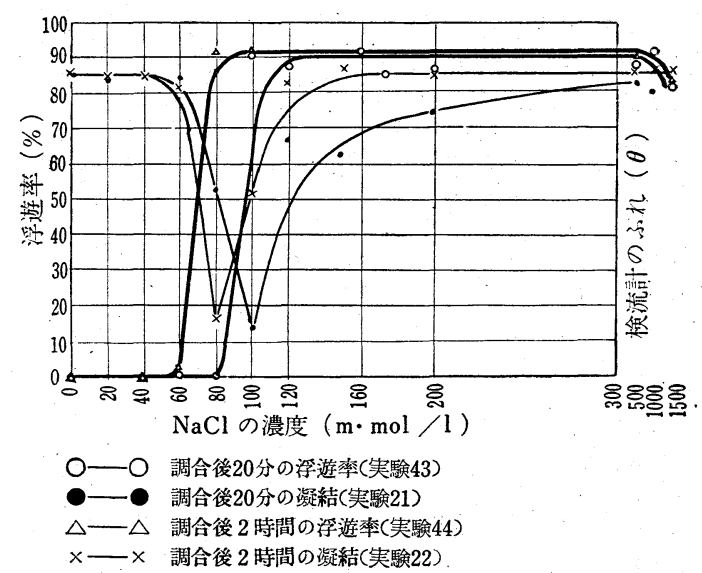

第 8 図 $\mathrm{As}_{2} \mathrm{~S}_{3}$ 膠質の凝結および浮遊率に対する $\mathrm{NaCl}$ の影響

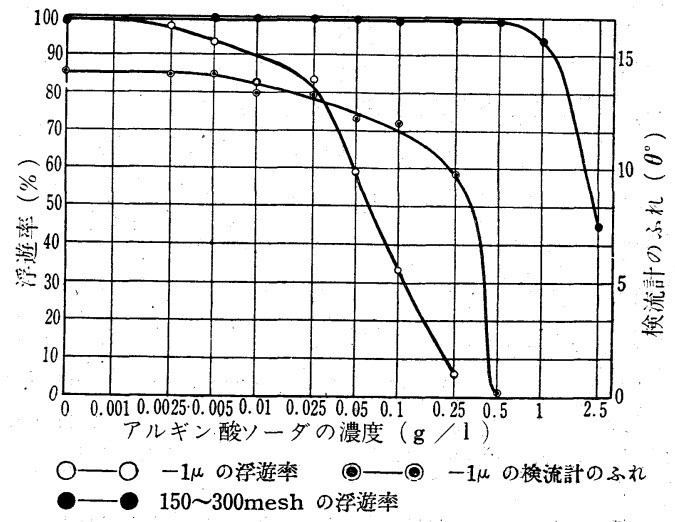

第10図 閃亜鉛鉱の浮遊率ならびに凝集におよ淁す アルギン酸ソーダの影響

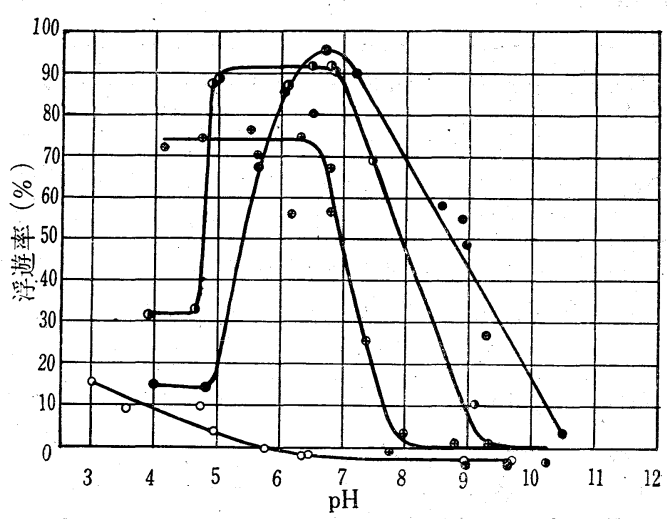

O- $\mathrm{O}-1 \mu$ の浮遊率 $\mathrm{ZnSO}_{4} 0.0 \mathrm{~m} \cdot \mathrm{mol} / \mathrm{l}$

$\oplus-\oplus .-1 \mu$ の浮遊秉 $\mathrm{ZnSO}_{4} 0.1 \mathrm{~m} . \mathrm{mol} / l$

-1- - $1 \mu$ の浮遊梨 $\mathrm{ZnSO}_{4} 0.4 \mathrm{~m} \cdot \mathrm{mol} / \mathrm{l}$

-— - $-1 \mu$ 浮遊率 $\mathrm{ZnSO}_{4} \quad 0.7 \mathrm{~m} \cdot \mathrm{mol} / \mathrm{l}$

第12図 $\mathrm{ZnSO}_{4}$ 添加に括ける閃亜鉛鉱の浮遊率に およ活す $\mathrm{pH}$ の影響 
ある。第3困から 150〜300mesh と - 1 浮遊性に著しい相違が認められる。この結果は箐者の 1 人20)がさきに報告した結果ときわめてよく符合する。一 $1 \mu$ 鉙粒の浮遊率ほ鈜粒の沈降のわずかに認められる $\mathrm{pH}$ 飞和いてやや増加する。

第 4〜7図はそれぞれ閃覀鉛鉣の浮遊率と $\mathrm{NaCl}, \mathrm{Ag}$ $\mathrm{NO}_{3}, \mathrm{CuSO}_{1}, \mathrm{ZnSO}_{4}$ の濃度との関係を示したもので ある。150〜300mesh の鉣粒の浮遊率は実験の濃度範囲 飞和いて $\mathrm{NaCl}, \mathrm{AgNO}_{3}, \mathrm{CuSO}_{4}, \mathrm{ZnSO}_{4}$ の濃度のいか んにかかわらずきわめてよく浮遊する。

$-1 \mu$ 鉣粒の浮遊率は電解質の濃度が小なる場合はほ とんど 0である。乙かし $\mathrm{NaCl} 2.5 \mathrm{~m} \cdot \mathrm{mol} / l, \mathrm{AgNO}_{3}$ $0.00025 \mathrm{~m} \cdot \mathrm{mol} / l, \mathrm{CuSO}_{4} 0.0025 \mathrm{~m} . \mathrm{mol} / l, \mathrm{ZnSO}_{4} 0.01 \mathrm{~m}$. $\mathrm{mol} / l$ 以上の濃度に和いて上昇し始めついに $100 \%$ に近 くなる。一方光電管による測定の結果著しく高い浮遊率 を示す濃度に和いて鉱粒の沈降は明瞭に認められ特に $\mathrm{CuSO}_{4}$ 泾よび $\mathrm{ZnSO}_{4}$ 添加の場合鉱粒の凝集はきわめ て顕著である。乙かし浮遊率を示す曲線と検流計のふれ を示す曲線との間には多少のずれが認められる。ここで 粒子の凝集または分散を明確に観測乙得る人工硫化物膠

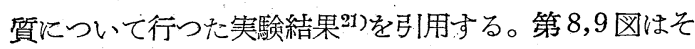
れぞれ $\mathrm{As}_{2} \mathrm{~S}_{3}, \mathrm{Sb}_{2} \mathrm{~S}_{3}$ 膠質の凝結和よび浮遊率と $\mathrm{NaCl}$ の濃度との関係を示したものである。 $\mathrm{As}_{2} \mathrm{~S}_{3}$ および $\mathrm{Sb}_{2}$ $\mathrm{S}_{3}$ 膠質はいずれも $\mathrm{NaCl}$ のある濃度以上飞和いて浮遊 しはじめる。この時膠質の凝結西同時に認められ検流評 のふれを示す曲線は下降する。さらに $\mathrm{NaCl}$ の濃度が堌 加すれば浮遊率は $100 \%$ に近く上昇する。この時 $\mathrm{As}$ 。 $\mathrm{S}_{3}, \mathrm{Sb}_{2} \mathrm{~S}_{3}$ 粒子は凝結の結果沈降状態に入り検流哔のふ れを示す曲線は上昇する。閃覀鉛鉱の $-1 \mu$ 粒子の䀣濁 液に関してはいわゆる透明膠質液に和けるごとく，凝集 の開始点を認めることは困難で，鈜粒が沈降する状態に 大つて始めて曲線が上昇する。このため検流計のふれを 示す曲線と浮遊率を示す曲線との閒に多少のずれが認め られるものと思われる。

第10図はアルギン酸ソーダの影響を求めた実験結果を 示乙たるのである。アルギン酸ソーダには強力な分散効 果が期待されるので実験は試料鈜液に $\mathrm{CuSO}_{4} 1.0 \mathrm{~m}$. $\mathrm{mol} / l$ を添加乙鉙粒を凝集状態に和き，これにアルギン 酸ソーダを添加してその影響を求めた。その結果 150〜 300 mesh の鈗粒についてはアルギン酸ソーダの濃度が 低、時は浮遊率は汪とんど $100 \%$ 近い。乙かしアルギ ン酸ンーダの濃度が著しく高くなれば浮遊率は低下す る。 $-1 \mu$ 鉱粒については凝集状態に特いては浮遊率は きわめて高く, アルギン酸ソーダの濃度が増加し鉱粒の 分散効果が認められる時浮遊率は著しく低下する。

以上の実験の結果から電解質の浮遊率に蛙よぼす影響 は $-1 \mu$ の微細鉱粒について顕著であり，人工硫化物の
膠質について認められた凝結と浮遊率との関係は閃亜鉛 鉱の微細粒子について $\mathrm{NaCl}_{2} \mathrm{AgNO}_{3}, \mathrm{CuSO}_{4}, \mathrm{ZnSO}_{4}$ およびアルギン酸ソーダを添加した場合に明瞭に認めら れる。

N. W. Taylor, H. B. Bul122)氏あるいは A. M. Gaudin 239 氏の認めた陽イオンによる抑制効果は本実験の 結果からは粗大粒子についてる認められない。このこと は電解質の種類, 濃度なとの害験の条件の相違に由来す る互のかと思われる。N. W. Taylor, H. B. Bull 氏の 実験に㑧ける電解質の濃度は本実験のそれより著しく高 w。

次にー $1 \mu$ 鉣粒の浮遊率に対する $\mathrm{CuSO}_{4}$ 肪よび $\mathrm{ZnSO}_{4}$ の影響をさらに確める目的をるつて $\mathrm{CuSO}_{4}$ の濃度 0 , $0.05,0.4 \mathrm{~m} . \mathrm{mol} / l, \mathrm{ZnSO}_{\text {; }}$ の濃度 $0,0.1,0.4,0.7 \mathrm{~m}$. $\mathrm{mol} / l$ について鉱液の $\mathrm{pH}$ そ 3 12 飞変化した時の浮 遊率を求めた。実験の結果第 11,12図に示すようであ る。微細鈗粒の浮遊率は $\mathrm{CuSO}_{4}$ の添加により $\mathrm{pH}$ の広 い範囲で腥しく高くなる。 $\mathrm{ZnSO}_{4}$ の影響は $\mathrm{CuSO}_{4}$ のよ 万に単純ではない。 $\mathrm{ZnSO}_{4}$ の濃度 $0.1,0.4,0.7 \mathrm{~m} \cdot \mathrm{mol} / l$ いずれの場合も鉱液の $\mathrm{pH}$ が高い場合は浮遊率は著しく 低下寸る。 $\mathrm{ZnSO}_{4}$ によ浮遊率の著しく高くなる $\mathrm{pH}$ の領域は比較的せまい。

電解質の鉣物浮遊性に和上ほす影響は複雑で画一的に のへることはできないが，本実験の結果から電解質によ る鉣粒の凝集または分散が微細鉣粒の浮遊性儿影響を岕 たえる要因の一つであることは明らかと思われる。

\section{4. 総括}

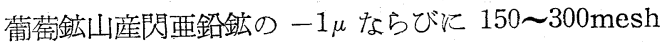
鉣粒の浮遊率に対する鈗液の水素イオン濃度牤よび $\mathrm{Na}$ $\mathrm{Cl}, \mathrm{AgNO}_{3}, \mathrm{CuSO}_{4}, \mathrm{ZnSO}_{4}$, アルギン酸ソーダの影響を 求めた実験の結果を総括寸れば次のようである。

(1) $-1 \mu$ 鉣粒の浮遊率は鉣液の $\mathrm{pH}$ の広い範囲で 著しく低い。乙かし 150～300mesh の鉙粒はきわめてよ く浮遊し， $-1 \mu$ 鉱粒と $150 \sim 300$ mesh 鈜粒との間に浮 遊性の璱しい相違が認められる。

(2) $-1 \mu$ 鉣粒の浮遊率は $\mathrm{NaCl}, \mathrm{AgNO}_{3}, \mathrm{CuSO}_{4}$, $\mathrm{ZnSO}_{4}$ の濃度低く鉱粒が分散状態を呈する時 0 に近く, 電解質の濃度高く鈗粒の凝集の進行した状態では 100\% に近く上昇し, 電解質の濃度の变化により浮遊率は添ほ $0 \sim 100 \%$ 変化を示す。

（3） $-1 \mu$ 鉣粒の浮遊率はアルギン酸ソーダの分散 効果にしたがい浮遊率は低下する。

(4) 150〜300 mesh 鉣粒の浮遊率に対する $\mathrm{NaCl}$, $\mathrm{AgNO}_{3}, \mathrm{CuSO}_{4} \mathrm{ZnSO}_{4}$ の濃度の影響は $-1 \mu$ 鉱粒に和 けるほど顕著には認められない。

(5) $\mathrm{CuSO}_{4}$ は鉱液の $\mathrm{pH}$ の広い範囲で $-1 \mu$ 鉱粒 
の浮遊を著しく促進し, $\mathrm{ZnSO}_{4}$ は鉣液の $\mathrm{pH}$ の比較的 狭い範围で $-1 \mu$ 鉣粒の浮遊を促進する。

\section{謝辞}

実験の試料を提供された葡萄鉣業所長緒方乙丸氏, 研 究に多大の御援助老与兄られた京都大学西原清廉教授, 九州大学前田孝矩教授, 伊藤尚教授, 越山季一教授, 大 森恭輔教授汇深厚の感謝をささげる。

\section{文献}

1) W. Petersen: Schwimmaufbereitung, 1936, 97 105.

2) A F. Taggart, T. C. Taylor, A. F. Knoll: Trans. A. I. M. E., Milling Methods, 1930, 217 260.

3) O. Sommer: Schwimmaufbereitung(Petersen),1936, 102 103; Metall u. Erz, 29, 1932, 268 269.

4) E. Edser: Flotation (Gaudin), 1932, 49.

5) H. L. Sulman: Flotation (Gaudin), 1932, 49.

6) A. M. Gaudin: Flotation, 1932, 49.

7) N. W. Taylor, H. B. Bull : Jour. Phys. Chem., 33, 1929, $641 \sim 655$.
8）大山 正：優先浮遊選鉱新論，昭和 7 年，79 130.

9) A. F. Taggart, G. R. M. del Giudice, O. A. Ziehl : Trans. A. I. M. E., 112, 1934, 348 381.

10) A. W. Fahrenwald, J. Newton: Eng. Mining Jour., Jan., 1937, 23 28.

11) T. C. Fitt, A. W. Thomas, A. F. Taggart: Trans. A. I. M. E., 153, Metal Mining, Milling Methods, 1943, 493 499 .

12) 根谷 敬：名古屋工業技術試験所報告, 4 卷, 1 号 $1955,41 \sim 45$.

13）向井 滋: 日本鉱業会誌, 68突, 769号, 昭和 27 年, 313 318.

14) 向井 滋: 九州大学生產科学研究所報告, 17 号, 昭和 30 年 $22 \sim 46$.

15) 向井 濼: 日本鉱業会誌, 69 卷, 782 号, 昭和 28 年, $291 \sim$

16) 向井 滋: 九州大学生產科学研究所報告, 17号,昭和 30 年, $1 \sim 21$.

17) 向井 滋：16) ミ同じ

18) 向井 滋: 16) ミ同じ

19）向井 滋: 九州大学生產科学研究所報告, 16 号, 昭和 30 年

20). 向井 滋：15)，16）气同心

21) 向井滋: 14) ミ同じ

22) N. W. Taylor, H. B. Bull : 7) ミ同心゙

23) A. M. Gaudin: Principles of Flotation (Sutherland, Wark), 1955, 67 68.

\section{特許出 願 公告 (鉣業関係)}

\begin{tabular}{|c|c|c|c|c|c|c|c|c|c|c|c|c|}
\hline \multirow{3}{*}{$\begin{array}{l}\text { 公告 } \\
\text { 番号 } \\
1101\end{array}$} & \multirow{2}{*}{ 分 } & & \multirow{2}{*}{ 頑書番号 } & \multirow{2}{*}{ 発 } & \multirow{2}{*}{ 明 } & \multirow{2}{*}{ の } & \multirow{2}{*}{ 称 } & \multicolumn{2}{|c|}{ 出 } & \multicolumn{3}{|c|}{ 願 人 } \\
\hline & & & & & & & & $\begin{array}{l}\text { 都府県 } \\
\text { 籍 }\end{array}$ & \multicolumn{4}{|c|}{ 名 (名称) } \\
\hline & 9 A 2 & 210 & $30-32927$ & 爆発性水流底 & 用試鉝 & 方法 & & 徳 - 島 & 中 & & 茂 . & \\
\hline 1102 & $\begin{array}{rrr}10 & \mathrm{~A} & 7 \\
(67 & \mathrm{J} & 5\end{array}$ & $\begin{array}{l}731.11 \\
51)\end{array}$ & $30-28345$ & 誘導加熱装置 & & & & 米. 国 & $\begin{array}{l}\text { ウエス } \\
\text { 坚ック }\end{array}$ & $\begin{array}{l}\text { チングハウ } \\
\text { コーポレ }\end{array}$ & $\begin{array}{l}\text { ウスス・エレ゙ } \\
\text { レーショシ }\end{array}$ & \\
\hline 1301 & $\begin{array}{rll}9 & \mathrm{~B} & 1 \\
(9 & \mathrm{A} & 2\end{array}$ & $\begin{array}{l}110.1 \\
210.1\end{array}$ & $28-597$ & 釯山用吸込式 & 揉錐， & & & 東 京 & 菊 & 川 & $\equiv$ & \\
\hline 1302 & 10 A 6 & 601 & $30-33933$ & 押 型 & & & & 神奈川 & タン & ガロイ & イ工 業(木 & \\
\hline 1303 & $\begin{array}{rrr}10 & \mathrm{R} & 1 \\
(14 & \mathrm{J} & 1\end{array}$ & $\begin{array}{l}121 \\
12)\end{array}$ & $28-20013$ & 粉末硫黄製造 & & & 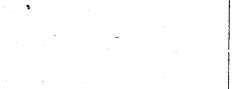 & 福 岡 & $\equiv$ & 戸 & 雅 & 逸 \\
\hline 1503 & $\begin{array}{rrr}10 & \mathrm{C} & 1 \\
(10 & \mathrm{J} & 2\end{array}$ & $\begin{array}{l}121.1 \\
221.2)\end{array}$ & $30-29827$ & 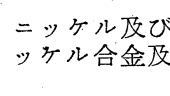 & マグネ & シウム & $\begin{array}{l}\text { を含む鉝石から二 } \\
\text { シウムを得る方法 }\end{array}$ & 千 葉 & 堀 & 居 & 太 & \\
\hline 1504 & $10 \mathrm{E} 1$ & 123 & $29-28996$ & チタニウムの & 電解製 & 造法 & & & 金属 & 材料 石 & 研 究 所 & \\
\hline 1505 & $10 \mathrm{R} 1$ & 122.2 & $30-15151$ & 硫黄釯の製釾 & & & & 東 京 & 三菱 & 金属 & 鉣 業（ & \\
\hline 1506 & $\begin{array}{lll}10 & \mathrm{P} & 1 \\
10 & \mathrm{P} & 2 \\
15 & \mathrm{~F}\end{array}$ & $\begin{array}{l}11 \\
\text { 22) } \\
\text { 2) }\end{array}$ & $30-9024$ & $\begin{array}{l}\text { 含微量ゲルマ } \\
\text { ヴ製造法 }\end{array}$ & ニウム & 絧鉣石 & より酸化グルマニ & 山 梨 & 武 & 内 & 次 & 夫 \\
\hline 1703 & $10 \mathrm{G} 2$ & & $30-16619$ & $\begin{array}{l}\text { 特殊構造の電 } \\
\text { 高き金属タン }\end{array}$ & . & ${ }^{2}$ & $\begin{array}{l}\text { 還元により純度 } \\
\text { 製造する方法 }\end{array}$ & 北海道 & 図 & 所 & 忠 & 則 \\
\hline 1705 & $10 \mathrm{~J} 2$ & 222.7 & $30-33534$ & ニッケル及ひ & :ュン゙ル & 卜を選 & 択分離する方法 & 米 国 & 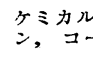 & レタュンン & ストラク & \\
\hline 1802 & $\begin{array}{lll}10 & \mathrm{E} & 1 \\
(12 & \mathrm{C} & \\
(10 & \mathrm{E} & 2\end{array}$ & $\begin{array}{l}121 \\
21) \\
221)\end{array}$ & $30-3257$ & $\begin{array}{l}\text { チタ二ウム㐬 } \\
\text { 合物を熱分解 }\end{array}$ & たはシ & & $\begin{array}{l}\text { ウムのハロゲン化 } \\
\text { 方法 }\end{array}$ & 東 京 & & 内 & 徳 & 保 \\
\hline 2001 . & $10 \mathrm{E} 1$ & 123 & $30-16318$ & チタンの改良 & 製造法 & & & 英 国 & $\begin{array}{l}\text { インぺリ } \\
\text { ダストリ }\end{array}$ & 际, & 多苏ル， & \\
\hline 2002 & $\begin{array}{lll}10 & \mathrm{H} & 1 \\
(10 & \mathrm{J} & 1\end{array}$ & $\begin{array}{l}1 \\
126)\end{array}$ & $30-24140$ & $\begin{array}{l}\text { 硫酸又は硫酸 } \\
\text { 鈗の団鈗法 }\end{array}$ & & & 加剤とするマン & 宋 京 & 发代モ & Eンド, & アルカリ, & カン \\
\hline
\end{tabular}

